\title{
Duch Betanii, styl Wieczernika. Józefa Życińskiego biblijne czytanie rzeczywistości
}

Ks. Dr hab. ANDrzej DraguŁA, Prof. US

Uniwersytet Szczeciński

O ks. abp. Józefie Życińskim mówi się przede wszystkim jako o filozofie, co jest oczywiście zrozumiałe. Jego dorobek naukowy to przede wszystkim prace $\mathrm{z}$ zakresu filozofii przyrody. O wiele rzadziej mówi się o arcybiskupie jako o teologu. Być może dlatego, że nie pozostawił po sobie monografii teologicznych czy naukowych rozpraw $z$ tej dziedziny. A przecież teologiem był przynajmniej z podstawowego, seminaryjnego wykształcenia. Realizacja jego teologicznego powołania wykracza jednak poza ten fundament. Zadaniem biskupa jest być także teologiem na ambonie. Jak pisze Jan Paweł II w posynodalnej adhortacji apostolskiej Pastores gregis, „mocą [...] własnej misji apostolskiej biskup jest zdolny wprowadzić swój lud w serce tajemnicy wiary, gdzie może spotkać się z żywą osobą Jezusa Chrystusa" ${ }^{1}$. Nawet jeżeli podobny obowiązek dotyczy

1 Jan Paweł II, Posynodalna adhortacja apostolska Pastores gregis, nr 27. 
także prezbitera i diakona, to ciąży on szczególnie na biskupie jako pierwszym nauczycielu wiary. Biskupi bowiem „w dniu święceń włączających ich w sukcesję apostolską, przyjmują jako główny obowiązek głoszenie Ewangelii”. Wspominając osobę arcybiskupa, trudno nie zadać pytania o to, w jaki sposób realizował on to wezwanie do bycia teologiem poprzez głoszenie Ewangelii. W przypadku abp. Życińskiego „ambonę” należy rozumieć jednak bardzo szeroko: nie tylko jako głoszenie kazań, ale także jako publicystykę teologiczną, którą z powodzeniem uprawiał, włączając do grona swoich odbiorców nie tylko słuchaczy, ale także czytelników.

\section{Publicystyka teologiczna}

35 punkt soborowej Konstytucji o liturgii Sacrosanctum concilium mówi, czym jest kazanie rozumiane jako „część czynności liturgicznej”. Jak podano w dokumencie, kazania (sermones) „Treść swoją powinny [...] czerpać przede wszystkim ze źródeł Pisma świętego i liturgii, jako zwiastowanie przedziwnych dzieł Bożych w dziejach zbawienia, czyli w misterium Chrystusowym, które zawsze jest w nas obecne i działa, zwłaszcza w obrzędach liturgicznych"3. To stwierdzenie soboru jest teologicznie niezwykle ważne,

2 Tamże, nr 26.

3 Konstytucja o liturgii świętej Sacrosanctum concilium, nr 35, w: Sobór Watykański II. Konstytucje, dekrety, deklaracje, Poznań 1967. 
a moim zdaniem wciąż niedoceniane. Treścią kazań - mówi dokument - winno być „misterium Chrystusowe”. Ma ono potrójną formę. Po pierwsze objawia się przede wszystkim „w przedziwnych dziełach Bożych w dziejach zbawienia”. Po wtóre „zawsze jest w nas obecne i działa”. Po trzecie - działa „zwłaszcza w obrzędach liturgicznych”. Pierwsza forma objawiania się misterium Chrystusa, to znaczy w dziejach zbawienia, jest czymś oczywistym. Ta trzecia forma - w obrzędach liturgicznych, może nie jest dla wszystkich oczywista, ale przecież konfrontujemy się z tą prawdą, ilekroć słyszymy w liturgii słowo hodie, czyli „dzisiaj”, które bardzo często pojawia się w wielkie święta. Mówimy przecież: dzisiaj się narodził, dzisiaj zmartwychwstał, dzisiaj wstąpił do nieba. Nie ma nic fałszywego ani w kolędzie Dzisiaj w Betlejem, ani w pieśni paschalnej Wesoły nam dzień dziś nastał. Dla wierzącego chrześcijanina wydarzenia zbawcze mają nie tylko charakter historyczny, ale także anamnetyczny, nie tylko były, ale i są, wydarzyły się i się dzieją w wiecznym teraz, a poprzez ryt liturgiczny stają się dzisiaj dostępne. Nie jest to koło wiecznych powrotów. To jest „teraz”, które raz się stając, wciąż się dzieje.

I jest jeszcze drugi wymiar, chyba najmniej oczywisty: misterium Chrystusa, które „zawsze jest w nas obecne i działa". Jeśli zasadniczo nie mamy problemu z usytuowaniem wydarzenia narodzenia Jezusa w liturgicznej tajemnicy świąt Bożego Narodzenia, czy też faktu zmartwychwstania w tajemnicy świąt wielkanocnych, to z rozpoznaniem tych wydarzeń i tych misteriów w naszym życiu 
jest już dużo trudniej. Bo co to znaczy, że narodzenie Pańskie, śmierć, zmartwychwstanie, ale także wszystkie inne wydarzenia $z$ dziejów zbawienia są w nas obecne i działają? Co to znaczy, że w naszym życiu staje się Wieczernik, Kalwaria, Betlejem, Jerozolima, Kafarnaum czy Emaus? A przecież - jak pisze Jerzy Szymik - dla teologii chrześcijańskiej „misterium Wcielenia” jest „podstawowym kluczem hermeneutycznym rozumienia całości"4. Dodajmy, że nie tylko to makromisterium Wcielenia, ale wszystkie mikromisteria życia Jezusa stanowią dla człowieka wiary, a na pewno dla teologa klucz hermeneutyczny do rozumienia całości rzeczywistości. Jest to zgodne ze stwierdzeniem adhortacji, w której czytamy, iż „w ten sposób wierni zrozumieją, że Pascha Chrystusa, zwycięzcy grzechu i śmierci, stanowi źródło i niezmienny punkt odniesienia dla całego doświadczenia chrześcijaństwa"

Wszystko to, co powiedziałem, dotyczy oczywiście w pierwszym rzędzie tego, co się nazywa posługą przepowiadania słowa Bożego, która realizowana jest przede wszystkim jako kazanie bądź homilia. Nie znaczy to jednak, że zasady te ograniczają się wyłącznie do tych form. Wciąż niedocenioną, a bardzo ważną formą głoszenia słowa Bożego jest publicystyka teologiczna, która nie jest wcale uproszczoną teologią, jakąś „teologią dla

4 J. Szymik, Teologia. Rozmowa o Bogu i człowieku, Lublin 20o8, s. 14.

5 Jan Paweł II, Posynodalna adhortacja apostolska Pastores gregis, nr 27. 
ludu" - wzorowaną na "filozofii dla ludu” rodem z Siłaczki Stefana Żeromskiego - pozbawioną metodologicznego reżymu, popularyzatorską formą katechizacji. Przeciwnie, uważam, że uprawianie publicystyki teologicznej wymaga przede wszystkim bardzo dobrej, ugruntowanej wiedzy teologicznej oraz zdolności językowych czy retorycznych, aby w niczym nie zakłamać teologicznej prawdy, a jednocześnie uczynić ją bardziej przystępną. Józef Majewski pisał: „w publicystyce teologicznej [...] owszem, chodzi o jakąś formę popularyzacji teologii, niemniej jednak dobra publicystyka jest zgoła czymś innym. Popularyzator jakiejś nauki zwykle pragnie jedynie przystępnie dla niewtajemniczonych czy niefachowców powtórzyć to, co dotychczas było dostępne tylko dla wtajemniczonych czy fachowców. W popularyzowaniu w nieunikniony sposób dochodzi do pewnych uproszczeń. [...] Publicystyka teologiczna nie jest (czystą) popularyzacją, chociaż z rozmysłem wykorzystuje jej warsztat [...]. Chodzi nie tyle o odtwarzanie w innej - przystępniejszej formie myśli i osiągnięć teologii akademickiej, ile o twórcze wykorzystanie i wplatanie ich w proces poszukiwania odpowiedzi w kontekście aktualnych, narzucających swoją czasową bezpośredniością pytań i problemów wiary"6.

W ten sposób dobrze uprawiana publicystyka religijna spełnia jedną z najważniejszych funkcji teologii, jaką jest funkcja krytyczna czy prorocka. Arcybiskup zgadza się

6 J. Majewski, Religia, media, mitologia, Gdańsk 2010, s. 131-132. 
z Jerzym Szymikiem, który pisał, że teologia jest najważniejszą nauką, bo daje możliwość oceny wszystkiego, całej rzeczywistości. „To ona - teologia - pisze Szymik - czuje się wśród nauk odpowiedzialna za «całość», za katolicką, holistyczną (od greckiego kat'holon - dotyczący całości) spójną wizję tego, co istotnie dotyczy człowieka, świata, życia"’. Po tym wstępie można już się domyśleć, że interesować mnie będzie ks. abp prof. Życiński jako publicysta teologiczny czy też jako teolog-publicysta. Przywołując kilka najczęściej pojawiających się u niego wyrażeń rozumianych przeze mnie jako klucze hermeneutyczne, chciałbym pokazać, w jaki sposób abp Życiński interpretował rzeczywistość jako miejsce, gdzie wciąż dzieje się zbawienie pozostające modelem chrześcijańskiego postępowania.

\section{Duch Wieczernika i lekcja Betlejem}

Pierwszy przykład to często pojawiające się wyrażenie „duch Wieczernika”. Czym jest dla Życińskiego Wieczernik? Jest przede wszystkim miejscem, z którego się wyrusza. „Musimy czuć się uczniami Wieczernika, którzy w Chrystusowym stylu powędrują najpierw w mrok Ogrójca, a następnie ku odległym lądom, aby zbawiać”. Życiński używa tego wyrażenia w tekstach opublikowanych $w$ roku 1997, aby przeciwstawić się pojawiającym się w Kościele

7 J. Szymik, Teologia. Rozmowa o Bogu i człowieku, dz. cyt., s. 14.

8 J. Życiński, Ziarno samotności, Kraków 1997, s. 12. 
tendencjom do zamknięcia się wobec zmieniającej się rzeczywistości społecznej i religijnej. Nazywa on to „mentalnością kapliczki”, „w której wprowadza się kult prywatnych bożków: pryncypialności, radykalizmu, uproszczonej do absurdu wizji świata. W cieniu prywatnych kapliczek szczególnie ulubioną czynność stanowi rzucanie kamieniami w stronę bliźnich, którzy chcieliby żyć duchem Wieczernika i nie zamierzają chronić się w zacisze kapliczek" 9 Skąd bierze się współcześnie taka mentalność? „Mentalność kapliczki może być ukształtowana przez różne mechanizmy. U jej podstaw może leżeć beztroska lub tryumfalizm, kompleks braku akceptacji albo zwyczajny lęk. Lęk może stanowić zagrożenie dla nas wszystkich, którzy doświadczamy bezradności, spotykając zagrożenia nieznane wcześniejszym generacjom. Łatwo wtedy straszyć i widzieć same negatywy w pejzażu, który mógł być objawieniem Bożej bliskości”" ${ }^{10}$. Zgoła inaczej postępują ci, którzy żyją duchem Wieczernika: „Dwunastka ruszyła z Wieczernika Zesłania w stronę nieznanych środowisk i obcych lądów, głosząc uniwersalną prawdę Dobrej Nowiny. Trzeba tylko umieć odchodzić od naszych prywatnych upodobań i towarzyskich sympatii, aby za cenę bólu odkrywać Jego uniwersalną prawdę"11. „Gdyby wystraszeni Apostołowie zrobili sobie w Wieczerniku wnikliwe podsumowanie

\footnotetext{
9 Tamże, s. 17.

10 Tamże, s. 21.

11 Tamże, s. 16
} 
zagrożeń czekających na nich w Koryncie czy w Rzymie, prawdopodobnie nie opuściliby swej ziemi rodzinnej"12.

Życiński ma świadomość, że lęk przed nieznanym światem, który nagle się otworzył przed Kościołem, jest w pewnym sensie oczywisty, naturalny i usprawiedliwiony. Pisze jednak, że najczęściej są to „lęki profilaktyczne”, w których „ujawnia się osad z naszych wcześniejszych rozczarowań i przegranych". Nie można jednak na tym poprzestać, znaczyłoby to bowiem, „że nie ma w nas wiary w moc i mądrość Ducha Świętego”. Zamiast wyruszać w stronę „rozległego horyzontu” chrześcijaństwo ograniczyłoby się „do poletka ograniczonego drutem kolczastym", a „w tym pejzażu nie sposób doświadczyć uniesień tamtego Wieczernika. Nie bylibyśmy już dziećmi wichru z Wieczernika, lecz towarzystwem adoracyjnym ze szczelnie zamkniętych kapliczek. Aby usprawiedliwić wprowadzone przemiany, wyjaśnilibyśmy wszystkim zainteresowanym, jak bardzo szkodliwe dla życia duchowego są przeciągi”' ${ }^{13}$.

Drugi klucz hermeneutyczny, który chciałbym przywołać, to Betlejem. Pojawia się on wtedy, gdy Życiński mówi krytycznie o pewnym kształcie współczesnego chrześcijaństwa w Polsce, które skupione jest na wizji triumfalistycznej i chciałoby ewangelizować bardziej siłą niż słabością. „Triumfalistyczny Mesjasz tradycyjnych wyobrażeń i tęsknot różnił się zasadniczo od bezsilnego Dziecięcia

\footnotetext{
12 Tamże, s. 21.

13 Tamże, s. 22.
} 
kwilącego w stajni" ${ }^{14}$ - zauważa Życiński. Tajemnica Betlejem to tajemnica słabości, a nie mocy i siły. Jakie to ma konsekwencje dla chrześcijaństwa? „Wierność dziedzictwu tamtej nocy każe nam odchodzić od dobrze znanych form i prostych schematów [...]. Każe ona również zrezygnować z pokusy powierzchownej chrystianizacji, w której powierzchowne rozwiązania ceni się wyżej niż pamięć o paradoksalnej sile słabości"15.

Istnieje jednak także taki typ chrześcijaństwa, który jest zaprzeczeniem lekcji płynącej z Betlejem: „Istnieje pewien typ cnoty, który miażdży żelazną logiką i nie widać w niej delikatności zbawiającego Boga"16 - pisze Życiński. Nie na tym jednak polega przekaz ewangelicznej prawdy. „Ten dystans między mocą nierozpoznanego Boga i kruchością naszych potencjalnych osiągnięć powinien skłaniać do pokory i wyciszenia w sytuacjach, w których zwykliśmy absolutyzować nasz punkt widzenia i stawiać sprawę na ostrzu noża, nawet wtedy, gdy idzie o kwestie zupełnie błahe. Elokwentnym besserwisserom, którzy zachowują się, jak gdyby mieli zbawiać świat przy pomocy krzyku, Zbawiciel przeciwstawia dyskretną ciszę nocy betlejemskiej" ${ }^{17}$. Z Betlejem wypływa jeszcze jedna ważna lekcja: „Być może ktoś z naszych pryncypialnych radykałów zatroszczyłby się, aby nie dopuścić pogańskich mędrców

\footnotetext{
14 Tamże, s. 209.

15 Tamże, s. 211.

16 Tamże, s. 212.

17 Tamże, s. 213.
} 
do Jezusa. Ostatecznie dałoby się otoczyć stajnię drutem kolczastym i nadać jej status getta, na teren którego mogliby wchodzić wyłącznie przedstawiciele sprawdzeni narodowościowo" ${ }^{18}$.

Betlejem to nie tylko słabość Boga i styl mędrców, to także lekcja, którą zostawia nam Herod. Życiński z niepokojem zauważa, że współcześnie miałby on wielu naśladowców. „Nie można wykluczyć, że po wprowadzeniu kilku dodatkowych modyfikacji okazałoby się, iż jedynym gościem dopuszczonym do groty Narodzenia byłby Herod. Obawiam się, iż niektóre dziedziny naszych rodzimych wydarzeń stosują się właśnie do tej wersji scenariusza. Dlatego też w ważnych polskich momentach potomkowie Herodów mają większą siłę przebicia niż mędrcy" ${ }^{19}$. Szczęśliwie, mędrcy „nie wzruszali się manifestowaną pobożnością spotykanych Herodów” - pisze Życiński. Dlaczego? Arcybiskup odpowiada: „Umiłowanie patetycznych form ekspresji nie zawsze idzie $\mathrm{w}$ parze $\mathrm{z}$ poczuciem elementarnej uczciwości. Odmiana słowa «naród» przez wszystkie przypadki nie musi bynajmniej wyrażać autentycznego szacunku dla narodu. Wiedzieli o tym mędrcy ze Wschodu i dlatego nie przywiązywali większej wagi do deklaracji Heroda, gdy zapewniał, że pragnie również oddać hołd Nowo Narodzonemu"2o.

18 Tamże, s. 217.

19 Tamże, s. 218.

20 J. Życiński, Samotność wśród liberałów, Lublin 2004, s. 129. 


\section{Metafory teologiczne}

Takich ewangelicznych matryc służących do czytania i interpretowania rzeczywistości jest w publicystyce Życińskiego bardzo wiele i powracają one wielokrotnie. Służą interpretacji nie tylko rzeczywistości społecznej, politycznej czy eklezjalnej, ale także osobistych doświadczeń. W tym ostatnim przypadku modelem hermeneutycznym pozostają tutaj wydarzenia z Betanii, dokąd Jezus przybywa, aby się spotkać z przyjaciółmi: Martą, Marią, Łazarzem. „Duch Betanii” to przede wszystkim duch gościnności i bliskości. „Wierność duchowi Betanii wymaga od nas duchowego wyzwolenia od presji zdarzeń i pytań typu «co ja dzisiaj podam gościom na obiad?», podnoszonych do rangi naczelnych problemów. Wierni stylowi zasłuchanej Marii, umiejmy zadumać się w obliczu tych życiowych spotkań, które wnoszą w nasze życie mądrość serca i piękno przyjaźni” ${ }^{21}$ - zauważa Życiński. I dalej: „Żyć duchem Betanii to znaczy mieć świadomość tego, że na ścieżkach naszego życia realne jest nie tylko ból i zło. Niemniej realne, a znacznie bardziej cenne, jest również doświadczenie dobra i piękna, jakie w swojej sztafecie pokoleń przejmujemy od osób, do których mogliśmy odnosić miano przyjaciół i mistrzów". Betanie mogą zdarzyć się codziennie i są azylem dla naszego człowieczeństwa. „W godzinie

${ }^{21}$ J. Życiński, Pożegnanie z Nazaretem, Lublin 200o, s. 237. 
nadchodzących życiowych burz dobrze jest się chronić do duchowej Betanii” ${ }^{22}$ - pisze Życiński.

Dla Życińskiego Ewangelia nieustannie się dzieje. Dzisiejsze wydarzenia są echami tych, które miały miejsce za życia Jezusa. Można w te wydarzenia wkroczyć, rozpoznać się w nich, przyjąć je za model postępowania. W życiu człowieka wydarza się Betlejem, Wieczernik, Emaus. Wydarzyć się może także - niestety - prowincjonalny Nazaret: „Prowincja, zarówno geograficzna, jak i intelektualna, ma swoje własne autorytety i lokalną mądrość; nie trzeba już żadnych Mesjaszów, którzy wnoszą zakłócenia w uporządkowane życie małego światka. [...] Wystarczy wytarty stereotyp i gładki slogan zabijający myślenie. Wskazany jest też pryncypialny krzyk jako środek niosący wyciszenie wątpliwości i poprawę samopoczucia u krzyczących. Ich głębokie samouwielbienie przejawia się w tym, że potrafią zgorszyć się nawet samym Chrystusem i wykazać mu niestosowne zachowanie" ${ }^{23}$. Może także wydarzyć się Emaus: „Od apostołów wędrujących do Emaus musimy wszyscy nauczyć się stylu przezwyciężania naszych rozczarowań dzięki spotkaniom z Chrystusem, który przychodzi w słowie i Eucharystii”"24. Emaus - podobnie jak Wieczernik - jest antytezą negatywnych tendencji w Kościele polskim: „Karykaturalnym zniekształceniem tej

\footnotetext{
22 Tamże.

23 Tamże, s. 27.

24 Tamże, s. 167.
} 
wspólnoty pozostają publicystyczne wizje, w których oblężony Kościół jawi się jako miejsce walki, zaś utrzymana w wojskowym stylu retoryka zastępuje zarówno modlitwę, jak i odniesienie do wartości duchowych"25. Może jednak także - oby jak najczęściej - wydarzyć się Galilea: „Wreszcie trzeba w każdej sytuacji odbudować nadzieję, pamiętając, że sam Jezus wyprzedza nas na spotkanie w słonecznej Galilei, gdzie można znowu odbudować utracony świat nadziei, piękna, sensu"26.

W Konstytucji Gaudium et spes Soboru Watykańskiego II czytamy, że „Kościół ma zawsze obowiązek badać znaki czasów i wyjaśniać je w świetle Ewangelii, tak aby mógł w sposób dostosowany do mentalności każdego pokolenia odpowiadać ludziom na ich odwieczne pytania dotyczące sensu życia obecnego i przyszłego oraz wzajemnego ich stosunku do siebie. Należy zatem poznawać i rozumieć świat, w którym żyjemy, a także jego nieraz dramatyczne oczekiwania, dążenia i właściwości"27. Teologiczna koncepcja znaków czasu pozwala dostrzegać dziejącą się historię ludzką jako przestrzeń dokonującej się wciąż Bożej ekonomii zbawienia. Ta kairologiczna optyka pozwala rozumieć każdy moment historii jako wyzwanie dla wiary.

25 Tamże, s. 169.

26 J. Życiński, Samotność wśród liberałów, dz. cyt., s. 130.

${ }_{27}$ Konstytucja duszpasterska o Kościele w świecie współczesnym Gaudium et spes, nr 4, w: Sobór Watykański II. Konstytucje, dekrety, deklaracje, Poznań 1967. 
Nawet ta skrótowa $\mathrm{z}$ konieczności lektura publicystyki ks. abp. Życińskiego pozwala na stwierdzenie, że tak właśnie dziejącą się rzeczywistość widział ten wybitny myśliciel, teolog i pasterz. Świat nie był dla niego jakimś manichejskim polem rozgrywki między dobrem a złem. Przeciwnie, był miejscem, w którym wciąż dzieje się, staje, odnawia historia zbawienia, tzn. wkroczenie Boga w świat, by ten świat przemienić, a człowieka zbawić. „W metaforycznym języku teologii [...] można wyrazić głęboką prawdę o naturze człowieka. Jej chrystocentryzm stanowi klucz do zrozumienia tajemnic współczesnej kultury. Tylko Chrystus może przynieść rozwiązanie bolesnych problemów znaczących naszą codzienność" - pisał ks. abp Życiński we wstępie do monografii Jerzego Szymika o inkarnacyjnej koncepcji teologii ${ }^{28}$. Dodam, że nie tylko może przynieść rozwiązanie owych bolesnych problemów codzienności, ale najpierw pozwala tę codzienność poprawnie zinterpretować. Albowiem to jedynie teologia - jak zauważył cytowany już Szymik - zna „całą” prawdę o człowieku. Majewski tak pisał o publicystyce katolickiej: „Publicystyka, inaczej niż popularyzacja, nie tyle chce powtarzać, ile ma coś do powiedzenia od siebie, inspirowana aktualnym życiem i karmiona teologią najwyższych akademickich lotów"29. Ksiądz abp Życiński wypracował własny styl publi-

${ }_{28}$ J. Życiński, Teologia o ludzkim obliczu. Przedmowa, w: J. Szymik, Teologia. Rozmowa o Bogu i człowieku, dz. cyt., s. 7.

29 J. Majewski, Religia, media, mitologia, dz. cyt., s. 132. 
cystyki inspirowanej filozofią, teologią, kulturą, a przede wszystkim Biblią, która pozostała dla niego księgą żywą. Z niej czerpał metafory do opisania rzeczywistości, które zakorzenione były w słowie Bożym, i czynił je matrycami do interpretowania rzeczywistości, jak duch Wieczernika, styl Betanii, lekcja Betlejem i inne. Myślę, że można w tekstach ks. abp. Życińskiego znaleźć wszystkie wskazane przez Majewskiego cechy dobrej publicystyki religijnej: oryginalność, inspirację życiem i teologię najwyższej próby. W jej uprawianiu ks. abp Życiński pozostaje wciąż niedoścignionym wzorem, a ona sama jest nadal niepokojąco aktualna. 